\title{
CHRONIC EFFECTS OF A MONOAMINE OXIDASE-INHIBITING ANTIDEPRESSANT: DECREASES IN FUNCTIONAL $\alpha$-ADRENERGIC AUTORECEPTORS PRECEDE THE DECREASE IN NOREPINEPHRINE-STIMULATED CYCLIC ADENOSINE $3^{\prime}: 5^{\prime}$-MONOPHOSPHATE SYSTEMS IN RAT BRAIN ${ }^{1}$
}

\author{
ROBERT M. COHEN,${ }^{*, 2}$ RICHARD P. EBSTEIN, ${ }^{\ddagger .3}$ JOIIN W. DALY, ${ }^{\ddagger}$ AND DENNIS L. MURPHY* \\ ${ }^{*}$ Clinical Neuropharmacology Branch, National Institute of Mental Health and ${ }^{\ddagger}$ Laboratory of Bioorganic Chemistry, \\ National Institute of Arthritis, Metabolism and Digestive Diseases, Bethesda, Maryland 20205
}

Received November 2, 1981; Revised April 9, 1982; Accepted May 7, 1982

\begin{abstract}
Various antidepressant drugs (monoamine oxidase inhibitors and tricyclics) enhance norepinephrine availability and lead to adaptive changes in brain noradrenergic systems, namely, decreases in the number of $\beta$ receptors and in the responsiveness of adenylate cyclase to norepinephrine stimulation. After 21 days of treatment with $1 \mathrm{mg} / \mathrm{kg} /$ day of clorgyline, an A-type-selective monoamine oxidase inhibitor, but not after 3 days, there is an increase in norepinephrine release from rat brain microsacs in response to $43 \mathrm{mM} \mathrm{KCl}$ stimulation. Microsacs prepared from 21-day clorgyline-treated animals also show a marked decrease in the inhibition of norepinephrine release caused by the $\alpha_{2}$-selective agonist clonidine. These functional changes in norepinephrine release mechanisms are accompanied by a $53 \%$ reduction in brainstem $\alpha_{2}$ receptor density as measured by $\left[{ }^{3} \mathrm{H}\right]$ clonidine binding. At the same time, despite findings of a decrease in $\beta$ receptor number as determined by $\left[{ }^{3} \mathrm{H}\right]$ dihydroalprenolol binding data, no significant decrease in the responses of cyclic adenosine $3^{\prime}: 5^{\prime}$-monophosphate (cyclic AMP) systems to norepinephrine stimulation is observed. Decreases in the cyclic AMP response are observed by day 35 of clorgyline treatment. The results provide direct physiological support for a change in the norepinephrine release mechanism and an effect on autoreceptors, specifically, preceding postsynaptic adaptive changes in the instance of one antidepressant, clorgyline. Difficulties in observing such changes with other antidepressants may result from the multiple nature of $\alpha$-adrenergic receptors, especially as measured by radioactive ligand techniques; the lack of a direct relationship between physiological changes and receptors as measured by radioligand techniques; the large doses of monoamine oxidase inhibitors used in some studies; and the possible multiplicity of antidepressant molecular mechanisms.
\end{abstract}

Chronic administration of antidepressants to rats leads to decreases in $\beta$-adrenoreceptor numbers and to a decrease in the norepinephrine-elicited accumulations of cyclic adenosine $3^{\prime}: 5^{\prime}$-monophosphate (cyclic AMP) (Sulser et al., 1978). This decrease in norepinephrine responsivity is believed to be secondary to a preceding persistence of increased norepinephrine levels in the synapse

\footnotetext{
' We gratefully acknowledge the expert technical assistance of Catherine McLellan and Michelle Dauphin.

${ }^{2}$ To whom correspondence should be addressed at Clinical Neuropharmacology Branch, National Institute of Mental Health, National Institutes of Health Clinical Center, Building 10, Room 3D41, Bethesda, MD 20205.

${ }^{3}$ Permanent address: Jerusalem Mental Health Center, Jerusalem, P.O.B. 140, Israel.
}

(Wolfe et al., 1978; Schweitzer et al., 1979). Several investigators have provided evidence that this decrease is partially mediated through a change in the presynaptic release mechanisms involving a reduction in local negative feedback (Crews and Smith, 1978; Svensson and Usdin, 1978; Tang et al., 1978; Spyraki and Fibiger, 1980). However, while radioligand binding data riemonstrated clear decreases in $\beta$ receptor numbers during antidepressant treatment, no analogous changes had been reported for $\alpha_{2}$-adrenergic receptors (Bergstrom and Kellar, 1979; Rosenblatt et al., 1979; Johnson et al., 1980). Recently, Cohen et al. (1982) provided data for a decrease in the number of $\alpha_{2}$-receptors which temporally preceded a reduction in $\beta$ receptor density in the rat cortex during chronic administration of clorgyline, a selective inhibitor of monoamine oxidase type A (MAO-A) which is a clin- 
ically effective antidepressant agent. These apparent inconsistencies between reports using different antidepressants may result from the existence of multiple $\alpha_{2}$-adrenergic receptors, some of which may play roles unrelated to presynaptic regulation. Therefore, it is important to examine directly norepinephrine release and the $\alpha_{2}$ receptor-mediated regulation of this release in the central nervous system during treatment with antidepressants such as clorgyline. A microsac preparation was chosen for these observations as the specific $\alpha_{2}$ receptor agonist clonidine had been demonstrated previously to decrease potassium chloride-stimulated norepinephrine release in a specific dose-dependent manner (De Langen et al., 1979). To examine the functional physiology of the $\beta$ receptor, the effect of norepinephrine stimulation on cylic AMP formation was examined in brain slices.

\section{Materials and Methods}

Animals. Six- to 12-week-old male Sprague-Dawley rats (175 to $200 \mathrm{gm}$ ) were obtained from Taconic Farms, Germantown, NY. Half of the animals were implanted with Alzet mini osmotic pumps (Alza Corp., Palo Alto, CA) containing concentrations of clorgyline that were adjusted to provide for continuous $1-\mathrm{mg} / \mathrm{kg} / \mathrm{day}$ administration to each animal. This dose is sufficient to produce greater than $90 \%$ inhibition of MAO-A (Campbell et al., $1979 \mathrm{a}, \mathrm{b})$. Animals were reimplanted every 2 weeks thereafter.

Assay of cyclic AMP generation. Cyclic AMP formation was measured by the adenine-prelabeling brain slice technique as originally described by Shimizu et al. (1969). This procedure results in data which are expressed as percentages of total radioactive adenine nucleotides present as cyclic AMP (percentage of conversion) and are in good agreement with those obtained from the measurements of endogenous levels of cyclic AMP in brain slices. Briefly, rats were sacrificed by decapitation and the brains obtained were placed in ice cold oxygenated Krebs-Ringer buffer (KRB). The brains were placed onto a chilled glass plate for dissection. The brainstem, cerebellum, and hypothalamus were removed and stored at $-80^{\circ} \mathrm{C}$ for enzyme and receptor assays at a later date. Sulall strips of cerebral cortical gray matter obtained with a single edge razor blade from two or three rats were placed into a second beaker of buffer. The strips then were sliced on a cooled block by a McIlwain tissue slicer set at $260 \mu \mathrm{m}$, rotated $180^{\circ}$, and sliced again. The tissue slices then were incubated at $37^{\circ} \mathrm{C}$ for $15 \mathrm{~min}$ in $15 \mathrm{ml}$ of buffer.

The preincubated brain slices were transferred to a third beaker containing adenine $(30 \mu \mathrm{M})$ and $\left[{ }^{3} \mathrm{H}\right]$ adenine $(20$ to $60 \mu \mathrm{Ci})$ and incubated at $37^{\circ} \mathrm{C}$ for $40 \mathrm{~min}$. The buffer was decanted; the slices were washed twice with buffer and then collected onto nylon mesh. Equal portions (10 to 12$)$ were transferred with stainless steel spatulas into $30-\mathrm{ml}$ beakers containing $10 \mathrm{ml}$ of buffer and allowed to equilibrate for $5 \mathrm{~min}$. Stimulating and blocking agents were added and time (10 $\mathrm{min})$ was allowed for stable maximal levels of cyclic AMP to form. Individual beakers were decanted, and tissue was collected onto nylon mesh, quickly transferred to conical homogenizing tubes containing $1 \mathrm{ml}$ of $6 \%$ trichloroacetic acid and unlabeled cyclic AMP $(0.25 \mu \mathrm{mol})$, and homogenized with a glass pestle. Homogenates were centrifuged for $10 \mathrm{~min}$ at $3,000 \mathrm{rpm}$. Fifty-microliter aliquots were taken from the supernatant fraction and the radioactivity was measured to determine the $\left[{ }^{3} \mathrm{H}\right]$ adenine nucleotide pool in each sample. The cyclic $\left[{ }^{3} \mathrm{H}\right] \mathrm{AMP}$ formed was determined by filtering and washing the remaining supernatant fraction through Dowex and alumina columns as described by Salomon et al. (1974).

Assay for norepinephrine release. Strips of rat cortex obtained as described above were homogenized by glass pestle in $10 \mathrm{vol}$ of Krebs-Ringer buffer at $4^{\circ} \mathrm{C}$. The homogenate was centrifuged at $1,000 \times g$ for $15 \mathrm{~min}$. The pellet was suspended in $10 \mathrm{vol}$ of buffer with $0.2 \mu \mathrm{M}\left[{ }^{3} \mathrm{H}\right]$ norepinephrine $(60 \mu \mathrm{Ci})$ added, and uptake was allowed to proceed for $30 \mathrm{~min}$ at $37^{\circ} \mathrm{C}$. The suspension was centrifuged at $1,000 \times \mathrm{g}$ for $5 \mathrm{~min}$ at $4^{\circ} \mathrm{C}$ and the pellet was resuspended in $10 \mathrm{vol}$ of buffer and centrifuged. The pellet was washed an additional two times in a similar manner. The final suspension of microsacs from a single cortex was in $10 \mathrm{ml}$ of calcium-free Krebs buffer. Three hundred-microliter aliquots of the suspension were added to $3 \mathrm{ml}$ of buffer and gently mixed. Two milliliters then were layered onto Sephadex G10 columns (polypropylene econo columns) for release experiments which were conducted at $25^{\circ} \mathrm{C}$. Each column ( 46 columns from the cortex of one rat) has a height of 0.75 to $1.0 \mathrm{~cm}$ and an approximate $0.2 \mathrm{ml} / 20 \mathrm{sec}$ flow rate. The columns were washed with $5 \mathrm{ml}$ of calcium-free Krebs buffer and the eluants were discarded. Columns then were washed with $2 \mathrm{ml}$ of the medium used for release, with the eluant collected directly into scintillation vials. The releasing eluant consisted of KRB plus varying concentrations of $\mathrm{KCl}$ ( $43 \mathrm{~mm}$ if not stated), $\mathrm{CaCl}_{2}(0.05 \mathrm{~mm}$ if not stated), and various concentrations of drugs (e.g., clonidine $(0.01$ to $10 \mu \mathrm{M})$ ). Prior to column preparation, aliquots were obtained for Lowry protein determination (Lowry et al., 1951) and for initial norepinephrine accumulation.

Assay for $\alpha$ - and $\beta$-adrenergic receptor binding. For each treatment group, six frozen $\left(-80^{\circ} \mathrm{C}\right)$ brainstem portions, approximating the region inclusive of medulla and pons, were weighed, thawed, and homogenized using a Polytron in $10 \%(\mathrm{w} / \mathrm{v})$ Tris-HCl $(50 \mathrm{~mm}, \mathrm{pH} 7.6)$ at $4^{\circ} \mathrm{C}$. The homogenates were centrifuged at $18,500 \times g$ for 10 $\min$ at $4^{\circ} \mathrm{C}$. The pellets were suspended in $50 \mathrm{vol}$ of buffer and centrifuged as before. The resulting pellets (prepared membranes) were resuspended in $10 \mathrm{vol}$ of buffer and used in the binding assay procedures.

For Scatchard determination (Scatchard, 1949) of $\alpha_{2}$ adrenergic receptor binding, $400-\mu l$ aliquots of the prepared membranes were added in triplicate to tubes containing the $\alpha_{2}$-adrenergic agonist $\left[{ }^{3} \mathrm{H}\right]$ clonidine (final concentrations ranged from 0.2 to 4 times $K_{D}$ ) in a total volume of $0.6 \mathrm{ml}$. Incubations were carried out at room temperature for $30 \mathrm{~min}, 7 \mathrm{ml}$ of cold $0.9 \%$ saline were added, and each tube was filtered rapidly through Whatman GF/C filters and washed with two additional $7-\mathrm{ml}$ quantities of cold $0.9 \%$ saline. The filters were placed in vials with $10 \mathrm{ml}$ of Ultrafluor and counted by liquid scintillation spectrometry. Specific binding is defined as the difference between the amount bound in the absence and presence of $10^{-5} \mathrm{M}$ phentolamine (U'Prichard et al., 
1977) and represented approximately $80 \%$ of the total $\left[{ }^{3} \mathrm{H}\right]$ clonidine bound at the $K_{D}$ value.

In the $\beta$ receptor assays, the final concentrations of 1 $\left[{ }^{3} \mathrm{H}\right]$ dihydroalprenolol, ranging from 0.2 to 4 times $K_{D}$, were incubated with $400-\mu \mathrm{l}$ aliquots of prepared membranes in a total volume of $0.6 \mathrm{ml}$. Samples were treated as in the $\alpha$ receptor binding assay with the exception of the substitution of GF/B filters. Specific binding is defined as the difference between the amount bound in the absence and presence of $10^{-5} \mathrm{M}$ propanolol (Bylund and Snyder, 1976). Specific binding was approximately $70 \%$ of the total.

Statistical analysis. $B_{\max }$ and $K_{D}$ values were formulated from estimates of the least squares analyses of Scatchard plots. Treatment and control differences in parameters were determined with the use of appropriate $F$ and two-tailed $t$ tests (Kleinbaum and Kupper, 1978).

Materials. Clonidine-HCl was obtained from Boehringer and Son, Ingelheim, West Germany; $\left[{ }^{3} \mathrm{H}\right]$ adenine and $\left[{ }^{3} \mathrm{H}\right]$ norepinephrine were from New England Nuclear, Boston, MA; ZK62771 was from Dr. H. Wachtel, Schering, A. G., Berlin; phentolamine-HCl was from Ciba Pharmaceutical Corp., Summit, NJ; $d l$-propranolol-HCl was from Sigma Chemical Co., St. Louis, MO; clorgyline was a gift of May and Baker Co., Essex England. Other compounds were from standard commercial sources. The Krebs-Ringer bicarbonate/glucose buffer contained 122 $\mathrm{mm} \mathrm{NaCl}, 3 \mathrm{~mm} \mathrm{KCl}, 1.2 \mathrm{~mm} \mathrm{MgSO}_{4}, 1.3 \mathrm{~mm} \mathrm{CaCl}_{2}, 0.4$ mM $\mathrm{KH}_{2} \mathrm{PO}_{4}, 10 \mathrm{~mm}$ glucose, and $25 \mathrm{~mm} \mathrm{NaHCO}$. All incubations were done in constant aeration with $95 \% \mathrm{O}_{2}$, $5 \% \mathrm{CO}_{2}$.

\section{Results}

The effects of clorgyline treatment on microsac norepinephrine release. Microsacs prepared from rats treated with clorgyline for 3 weeks differed significantly from those derived from control animals in the release of norepinephrine in response to a depolarizing agent (Table I). This enhanced norepinephrine release $(\sim 160 \%)$ in response to $43 \mathrm{mM} \mathrm{KCl}$ was observed over a range of $\mathrm{Ca}^{2+}$ concentrations $(0.05$ to $1.0 \mathrm{~mm})$ which has been reported previously to facilitate norepinephrine release (De Langen et al., 1979). These differences did not result from shifts in cortical norepinephrine accumulation as no differences were ever observed between norepinephrine uptake in microsacs prepared from control or clorgylinetreated animals (data not shown).

As previously observed (De Langen et al., 1979), clonidine, a specific $\alpha_{2}$-adrenergic agonist, significantly reduced $\left[{ }^{3} \mathbf{H}\right]$ norepinephrine release from microsacs prepared from control animals; however, clonidine failed to affect the $\left[{ }^{3} \mathrm{H}\right]$ norepinephrine release observed from similarly prepared microsacs from 21-day clorgyline-treated animals. Although $\mathrm{Ca}^{2+}$ was able to shift the clonidine dose-response curve to the right for control animals, it had little effect on the lack of responsiveness of microsacs prepared from the clorgyl:ne-treated animals. To confirm these observations, a second group of animals were similarly prepared and differences in the release properties were confirmed (data not shown).

To ascertain whether the differences observed in release between the microsacs prepared from the control and clorgyline-treated animals might result from differences in $\alpha$-adrenergic receptor properties as suggested by the clonidine data, the effect of phentolamine, a specific $\alpha$-adrenergic receptor blocker, on the release of $\left[{ }^{3}\right]$ norepinephrine was examined. At a concentration of phentolamine $(1.0 \mu \mathrm{M})$ sufficient to block the clonidine suppressant effect on release in control groups (Fig. 1), phentolamine eliminated the statistical difference between the clorgyline and saline groups, although small differences remained, which suggest that other mechanisms may account for some of the differences observed.

TABLE I

$\mathrm{KCl}(43 \mathrm{mM})$-stimulated $\left[{ }^{3} \mathrm{H}\right]$ norepinephrine release from microsacs prepared from rat cortex of control and 21-day clorgyline-treated animals in the presence of varying concentrations of $\mathrm{Ca}^{2+}$ and clonidine

Each result represents the mean \pm SEM of the disintegrations per min of $\left[{ }^{3} \mathrm{H}\right]$ norepinephrine released from the microsacs examined in 6 to 9 experiments as detailed under "Materials and Methods."

\begin{tabular}{|c|c|c|c|c|c|c|c|}
\hline & \multirow{2}{*}{$\mathrm{CaCl}_{2}$} & \multicolumn{6}{|c|}{ Clonidine } \\
\hline & & $0 \mu \mathrm{M}(n)$ & $0.01 \mu \mathrm{M}(\%)^{a}$ & $0.1 \mu \mathrm{M}(\%)$ & $0.5 \mu \mathrm{M}(\%)$ & $1.0 \mu \mathrm{M}(\%)$ & $5.0 \mu \mathrm{M}(\%)$ \\
\hline & $m M$ & \multicolumn{6}{|c|}{$d p m$} \\
\hline \multirow[t]{3}{*}{ Control } & 0.05 & $981 \pm 178(6)$ & $1,002 \pm 95(102 \%)$ & $529 \pm 117(54 \%)^{b}$ & & $443 \pm 189(45 \%)^{b}$ & \\
\hline & 0.10 & $2,163 \pm 137(9)$ & & $1,920 \pm 164(89 \%)$ & $1,552 \pm 131(72 \%)^{c}$ & $1,485 \pm 112(69 \%)^{c}$ & \\
\hline & 1.00 & $6,504 \pm 219$ & & $6,129 \pm 180(94 \%)$ & & $5,699 \pm 247(88 \%)^{d}$ & $5,502 \pm 268(85 \%)^{d}$ \\
\hline Clorgyline & 0.05 & $1,636 \pm 193(9)^{e}$ & $1,495 \pm 168(91 \%)$ & $1,517 \pm 210(93 \%)$ & & $1,237 \pm 201(76 \%)$ & \\
\hline
\end{tabular}

\footnotetext{
${ }^{a}$ Percentage of $0 \mu \mathrm{M}$ clonidine.

${ }^{b}$ Statistically significant clonidine suppression, $p<0.1$.

${ }^{c}$ Statistically significant clonidine suppression, $p<0.01$

${ }^{d}$ Statistically significant clonidine suppression, $p<0.05$

${ }^{e}$ Statistically significant differences between microsacs prepared from clorgyline-treated animals and controls in the absence of clonidine, $p$ $<0.01$.

' Statistically significant differences between microsacs prepared from clorgyline-treated animals and controls in the absence of clonidine, $p<$ 0.05 .

${ }^{g}$ Statistically significant differences between microsacs prepared from clorgyline-treated animals and controls in the absence of clonidine, $p$ $<0.001$.
} 


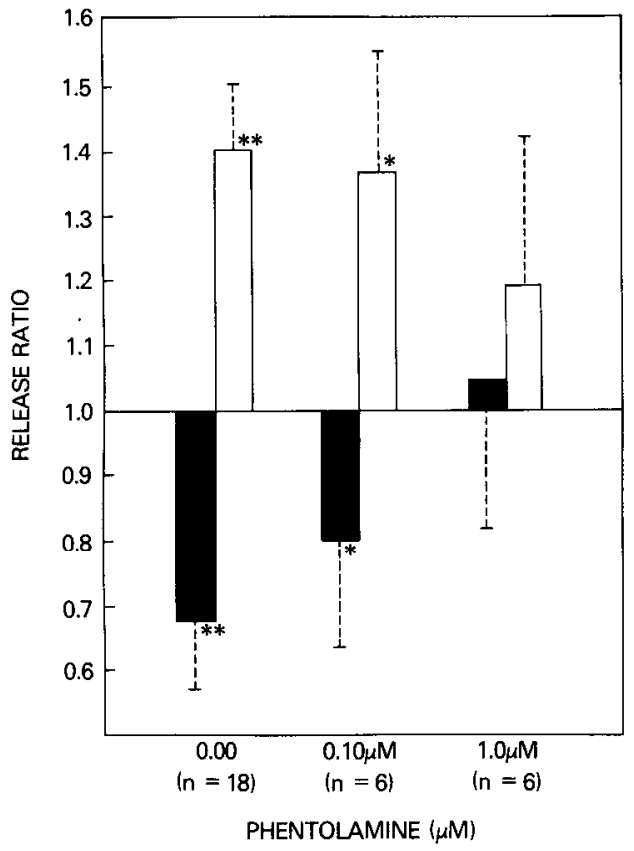

Figure 1. The dose-response effect of the $\alpha$-adrenergic antagonist phentolamine on $\mathrm{KCl}(43 \mathrm{~mm})$-stimulated release of $\left[{ }^{3} \mathrm{H}\right]$ norepinephrine from microsacs in the presence of $0.15 \mathrm{mM}$ $\mathrm{CaCl}_{2}$ as described under "Materials and Methods." The data are represented as ratios. The solid bars representing

\section{$\left[{ }^{3} \mathrm{H}\right]$ norepinephrine released with $1 \mu \mathrm{M}$ clonidine \\ $\overline{\left[{ }^{3} \mathrm{H}\right] \text { norepinephrine released in the absence of clonidine }}$}

in control microsacs reflect the effect of phentolamine on the $\alpha$-adrenergic agonist suppression of norepinephrine release and the open bars representing

$\underline{\left[{ }^{3} \mathrm{H}\right] \text { norepinephrine released from clorgyline-treated animals }}$

$\left[{ }^{3} \mathrm{H}\right]$ norepinephrine released from control animals

reflect the effect of phentolamine on the observed differences in $\mathrm{KCl}$ responsivity between control and 21-day clorgylinetreated rats. The values represent the mean ratios \pm SEM of 6 to 18 experiments. Statistically significant differences between control and clonidine (solid bars) or between microsacs prepared from control compared to clorgyline-treated animals (open bars) are represented by asterisks: $*, p<0.05 ; * *, p<$ 0.001 .

In a separate group of animals, the above differences were not observed between control microsacs and microsacs prepared from animals following only 3 days of clorgyline treatment (Table II). Also, in vitro incubation of the microsacs in the presence of $5 \mu \mathrm{M}$ clorgyline did not block the clonidine suppression of the release. At 0.15 $\mathrm{mM} \mathrm{CaCl}$, microsac release of norepinephrine in the presence of 0.2 and $0.5 \mu \mathrm{M}$ clonidine was $67.1 \%(p<$ $0.001)$ and $70.6 \%(p<0.01)$, respectively, of base line ( $n$ $=15$ ). In the same experiment, in the presence of $5 \mu \mathrm{M}$ clorgyline, release with 0.2 and $0.5 \mu \mathrm{M}$ clonidine was $69.3 \%$ $(p<0.05)$ and $67.1 \%(p<0.01)$, respectively, of base line values.

The effects of clorgyline treatment on norepinephrinestimulated cyclic AMP formation in brain slices. Following 21 days of $1-\mathrm{mg} / \mathrm{kg} /$ day clorgyline treatment, norepinephrine $(100 \mu \mathrm{M})$-stimulated cyclic AMP formation from brain slices was not affected significantly (Fig. 2). This was confirmed using phentolamine $(10 \mu \mathrm{M})$, an adrenergic antagonist known to block the $\alpha_{1}$ component of the norepinephrine response. This lack of effect was not the net result of a decrease in the production of cyclic AMP masked by a concomitant decrease in phosphodiesterase activity as the addition of ZK62771 (final assay concentration, $100 \mu \mathrm{M})$, a potent phosphodiesterase inhibitor (Schwabe et al., 1976), did not lead to significant differences $(6.38 \pm 1.06 \%$ and $5.67 \pm 0.50 \%$ conversion for controls and 21-day clorgyline-treated animals, respectively).

At 35 days, however, a significant decrease in the norepinephrine and norepinephrine-phentolamine stimulation was observed in the clorgyline-treated animals, with only $38.6 \%$ and $44.4 \%$ of the respective responses maintained. This response difference also was observed with $5 \mu \mathrm{M}$ norepinephrine, with the clorgyline-treated group exhibiting only $53.9 \%$ of control stimulation $\mathbf{( 1 . 1 5}$ $\pm 0.07 \%$ and $0.62 \pm 0.13 \%$ conversion for controls and clorgyline-treated animals, respectively). The response decrease was selective, as stimulation by $100 \mu \mathrm{M}$ adenosine $(1.97 \pm 0.37 \%$ and $1.76 \pm 1.11 \%$ for controls and clorgyline-treated animals, respectively) and $0.1 \mu \mathrm{M}$ vasointestinal peptide $(4.11 \pm 1.43 \%$ and $4.55 \pm 2.07 \%$ for controls and clorgyline-treated animals, respectively) did not differ in the two groups.

The effect of clorgyline treatment on adrenergic receptors. As previously observed (Cohen et al., 1982), 21 days of clorgyline treatment significantly reduced $\alpha_{2}$ and $\beta$ receptor brainstem densities by $53 \%(p<0.05)$ and $50 \%(p<0.001)$, respectively (Table III).

\section{Discussion}

The time course for adaptive changes in the central nervous system of the rat in response to selective MAOA inhibition has been investigated. At the clorgyline dose administered ( $1 \mathrm{mg} / \mathrm{kg} /$ day), about twice the usual clinical dose, it is clear that: (1) an increase in microsac norepinephrine release in response to $\mathrm{KCl}$ stimulation occurs by 21 days that is not observed on day 3 of clorgyline treatment. This effect is reasonably calcium independent. (2) The altered release to electrolyte stimulation is accompanied by a change in the responsivity of release to clonidine suppression. This near total escape from clonidine suppression occurs at varying calcium concentrations and appears to represent a change which is not simply a shift in the $K_{D}$ of clonidine binding. (3) No significant changes in cyclic AMP formation in response to norepinephrine stimulation is apparent at 21 days, but decreases are observed by day 35 of treatment with clorgyline. The characteristics of the response of norepinephrine stimulation of adenylate cyclase in brain slices of rat cortex suggest that both $\alpha$ and $\beta$ receptors play a role in its mediation (Daly et al., 1980 and references therein). The differences observed both with and without the presence of phentolamine in the experiments suggest that functional changes in both the postsynaptic $\alpha$ - and $\beta$-adrenergic receptors that are part of this mediation may have occurred by the 5 th week of treatment but not by the end of 3 weeks.

These findings of changes in the apparent local negative feedback system of the adrenergic pathway during 
TABLE II

$\mathrm{KCl}(43 \mathrm{mM})$-stimulated $\left[{ }^{3} \mathrm{H} /\right.$ norepinephrine release from microsacs prepared from rat cortex of control animals and rats on the 3rd day of clorgyline treatment at varying $\mathrm{Ca}^{2+}$ and clonidine concentrations

Each result represents the mean \pm SEM of the disintegrations per min of $\left[{ }^{3} \mathrm{H}\right]$ norepinephrine released as detailed under "Materials and Methods."

\begin{tabular}{|c|c|c|c|c|}
\hline & \multirow{2}{*}{$\mathrm{CaCl}_{2}$} & \multicolumn{3}{|c|}{ Clonidine } \\
\hline & & $0 \mu \mathrm{M}(n)$ & $0.2 \mu \mathrm{M}(n)$ & $0.5 \mu \mathrm{M}(n)$ \\
\hline & $m M$ & \multicolumn{3}{|c|}{$d p m$} \\
\hline \multirow[t]{2}{*}{ Control } & 0.05 & $959 \pm 73$ & $438 \pm 15(3)^{a}$ & $535 \pm 183(3)^{b}$ \\
\hline & 0.10 & $1,448 \pm 62$ & $622 \pm 80$ & $775 \pm 86(3)^{a}$ \\
\hline Clorgyline & 0.05 & $1,202 \pm 73$ & $571 \pm 175(3)^{a}$ & $303 \pm 172(3)^{\alpha}$ \\
\hline (3-day treatment) & 0.10 & $1,140 \pm 192(3)$ & $927 \pm 173(3)$ & $546 \pm 224(3)^{b}$ \\
\hline
\end{tabular}

${ }^{a}$ Statistically significant clonidine suppression, $p<0.01$.

${ }^{b}$ Statistically significant clonidine suppression, $p<0.05$.

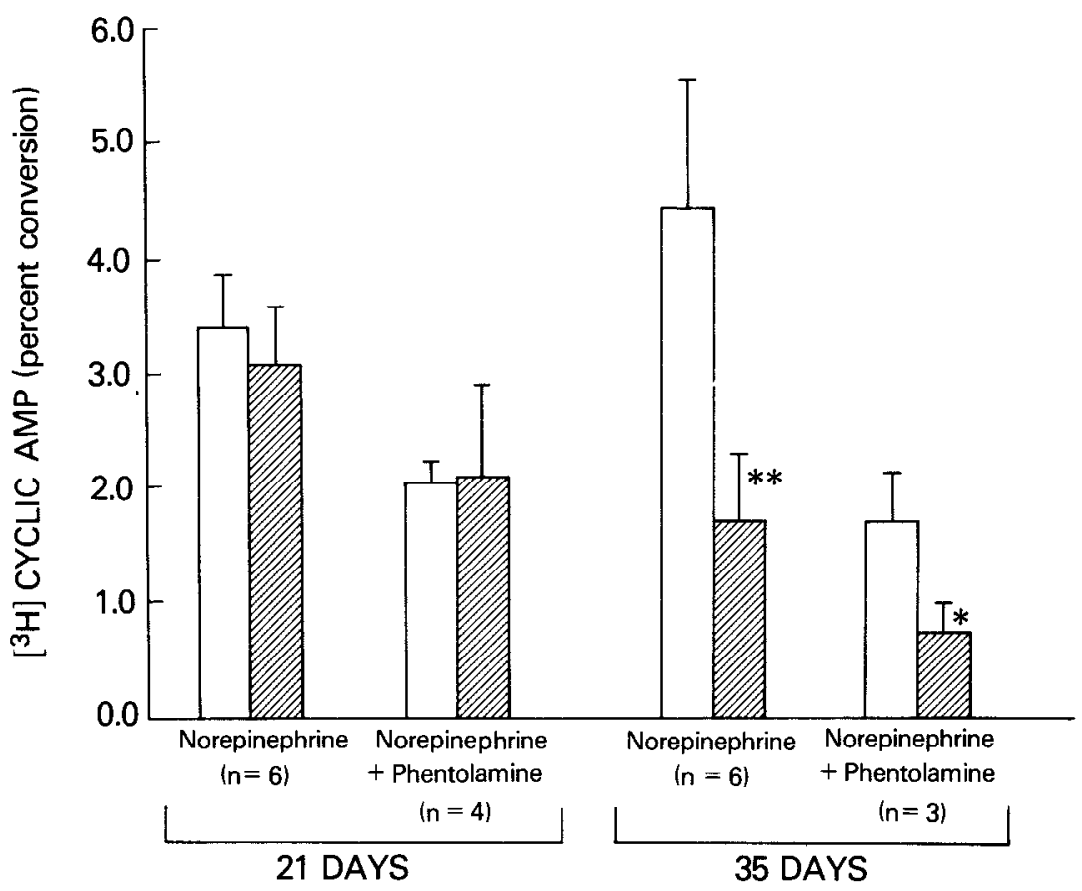

\section{TREATMENT (days)}

Figure 2. The effect of in vivo clorgyline treatment on the accumulation of radioactive cyclic $\Lambda \mathrm{MP}$ in adenine-labeled rat brain slices. Slices were incubated for $10 \mathrm{~min}$ with $100 \mu \mathrm{M}$ norepinephrine in the presence or absence of the $\alpha$-adrenergic antagonist phentolamine $(10 \mu \mathrm{M})$ and the accumulations of cyclic $\left[{ }^{3} \mathrm{H}\right] \mathrm{AMP}$ were measured as detailed under "Materials and Methods." The open bars represent values obtained from brain slices of control animals and the hatched bars are values obtained from brain slices prepared from animals which had been treated with clorgyline for the number of days indicated on figure. The values are the means \pm SEM for 2 to 6 experiments. Statistical differences were determined by the Student's $t$ test and significant differences are noted by asterisks: $*, p<0.05 ; * *, p<0.001$.

in vivo clorgyline treatment were reflected in the radioactive ligand binding assays utilizing $\left[{ }^{3} \mathrm{H}\right]$ clonidine. As previous work (Cohen et al., 1982) had demonstrated that both cortical and brainstem $\alpha_{2}$ and $\beta$ receptor numbers were decreased by in vivo clorgyline treatment, we were able to use the cortices for the release and adenylate cyclase studies and the brainstems from the same animals for the binding studies. This insured that the binding changes observed in the prior experimental groups actually were present in the same rats in which the catecholamine release and adenylate cyclase experiments were performed. The results are similar to those found with desipramine (Smith et al., 1981) but differ from other binding studies which have shown either no change in $\alpha$-adrenoreceptor number or increases in their number in response to other antidepressant regimens. These differences simply may reflect a diverse set of molecular mechanisms for the different classes of antidepressants. Alternatively, the apparent discrepancies may arise from the use of different radioligands and the multiple nature of $\alpha$-adrenergic receptors, including subpopulations of $\alpha_{2}$ receptors (U'Prichard et al., 1977; Morris et al., 1981; Vizi, 1979) that may respond to drug regimens differently. For example, whereas we have observed a decrease in 
TABLE III

The effect of 21 days of $1-\mathrm{mg} / \mathrm{kg} /$ day clorgyline treatment on brainstem $\alpha_{2}$ and $\beta$ receptors as determined by Scatchard analysis of $\left[{ }^{3} \mathrm{H}\right]$ clonidine and $\left[{ }^{3} \mathrm{H}\right]$ dihydroalprenolol binding

Each result represents a least squares estimate of $B_{\max }$ and $K_{D} \pm \mathrm{SE}$ (the standard error of the estimate) obtained as detailed under "Materials and Methods."

\begin{tabular}{|c|c|c|c|c|}
\hline & \multicolumn{2}{|c|}{ Control } & \multicolumn{2}{|c|}{ Clorgyline } \\
\hline & $B_{\max } \pm \mathrm{SE}$ & $K_{D} \pm \mathrm{SE}$ & $B_{\max } \pm \mathrm{SE}$ & $K_{n} \pm \mathrm{SE}$ \\
\hline & $\underset{\text { tein }}{\mathrm{fmol} / \mathrm{mg}}$ pro- & $n M$ & $\underset{\text { tein }}{\mathrm{fmol} / \mathrm{mg} \text { pro- }}$ & $n M$ \\
\hline $\begin{array}{l}\alpha_{2} \text { receptor } \\
{\left[{ }^{3} \mathrm{H}\right] \text { cloni- }} \\
\text { dine }\end{array}$ & $30.4 \pm 2.2$ & $2.6 \pm 0.4$ & $14.2 \pm 3.4^{a}$ & $1.3 \pm 1.0$ \\
\hline $\begin{array}{l}\beta \text { receptor } \\
{\left[{ }^{3} \mathrm{H}\right] \text { dihy- }} \\
\text { droalpreno- } \\
\text { lol }\end{array}$ & $30.5 \pm 0.96$ & $0.80 \pm 0.04$ & $15.2 \pm 1.6^{b}$ & $1.54 \pm 0.48$ \\
\hline
\end{tabular}

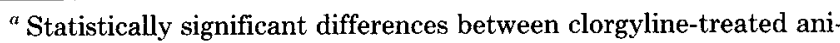
mals and controls, $p<0.05$.

${ }^{b}$ Statistically significant differences between clorgyline-treated animals and controls, $p<0.001$.

$\alpha_{2}$ receptor number and $\beta$ receptor number (Campbell et al., 1979b; Cohen et al., 1982) in response to an increasing availability of norepinephrine with clorgyline administration (Campbell et al., 1979a), Maggi et al. (1980) demonstrated an inverse relationship between $\alpha_{2}$ receptors and $\beta$ receptors in cortical slices incubated with isoproterenol. Dibner and Molinoff (1979) have observed differences in the process of rapid in vitro desensitization of $\beta$ receptors from the slower in vivo desensitization process. Similarly, measurement of $\alpha_{2}$ receptors by the use of a single or even multiple radioactive ligands will reflect the diverse adaptive mechanisms of the subpopulations of $\alpha_{2}$ receptors.

The decrease in $\beta$ receptor number in the brainstem is $50 \%$; however, it is important to realize that the adenylate cyclase system observed is that from the cortex. In our previous experiments, the $B_{\max }$ changes are magnified considerably in the brainstem as compared to the cortex and a more realistic decrease of about $34 \%$ would be expected to be present in the cortex. In part, the magnified $\beta$ receptor changes observed in the brainstem may reflect the use of the $\beta$ antagonist propanolol to determine specific binding. Propanolol appears to displace additional, perhaps "nonspecific" sites in comparison to the agonist isoproterenol in the brainstem but not the cortex (Stone and U'Prichard, 1981). Nevertheless, the decrease in $\beta$ receptor number, observed previously in the cortex after 21 days of clorgyline treatment, is not reflected immediately in a decrease in the norepinephrine stimulation of the adenylate cyclase system but only some time later. Similar discrepancies between receptor number and norepinephrine-stimulated cyclic AMP accumulation have been reported previously following other antidepressant regimens (Mishra et al., 1980), 6hydroxydopamine treatment (Skolnick et al., 1978), clonidine withdrawal (Kistler and Davis, 1980), and stress (Stone, 1981). These findings are not surprising in the context of our knowledge of the multistep process that comprises $\beta$ receptor-mediated adenylate cyclase regu- lation in tissue culture (Su et al., 1980). Previous reports of earlier changes in norepinephrine-stimulated adenylate cyclase responses following MAO inhibitor administration have used exceptionally high doses of drug: Vetulani et al. (1976a) used $75 \mathrm{mg} / \mathrm{kg}$ of pargyline and 100 $\mathrm{mg} / \mathrm{kg}$ of nialamide as initiating doses followed by 25 and $40 \mathrm{mg} / \mathrm{kg}$, respectively, daily for 20 days before differences were noted, and Wolfe et al. (1978) found a $20 \%$ decrease following 11 to 15 days of daily doses of $25 \mathrm{mg} /$ $\mathrm{kg}$ of pargyline. In contrast, the reports using tricyclic antidepressants show considerably more divergence but are still of interest in comparison to the available data on monoamine oxidase inhibitors. Whereas Vetulani et al. (1976b) reported that 4 to 8 weeks of desipramine or iprindole treatment were required before changes were apparent in the adenylate cyclase response to norepinephrine, Wolfe et al. (1978) observed changes after 1 day and a maximum change after 5 to 7 days of treatment with desipramine. Using $20 \mathrm{mg} / \mathrm{kg}$ of daily imipramine treatment, Frazer et al. (1974) and Schultz (1976) found differences by 5 and 6 days, respectively.

Overall, the results provide direct physiological support for a change in norepinephrine release mechanisms and, specifically, an effect on the presynaptic $\alpha_{2}$-adrenoreceptors (autoreceptors) in the rat brain secondary to some antidepressant treatments, an effect that had been inferred from peripheral norepinephrine release studies (Crews and Smith, 1978) and escape from clonidine-induced changes in metabolites (Tang et al., 1978), locus coeruleus firing rates (Svensson and Usdin, 1978; Campbell et al., 1979b), and locomotion (Spyraki and Fibiger, 1980). Indirect measures in man of clonidine challenges also have suggested a temporal pattern for decreasing $\alpha_{2}$ responsivity similar to that observed in the rat (Siever et al., 1981). Although, historically, enhancement of presynaptic release mechanisms in ways to enhance catecholamine availability was considered the mode of efficacy of antidepressants, the discrepancy between these acute effects of antidepressants and the longer time course of antidepressant efficacy had focused attention on postsynaptic adaptational changes. Some theories based on such changes have postulated that the down regulation of $\beta$ receptors may be the molecular mechanism of action of the antidepressants (Sulser et al., 1978), with an abnormally high catecholamine activity being the pathological lesion in depression (Segal et al., 1974). Since the $\beta$ receptor-mediated cyclic AMP response changes with clorgyline treatment occur 2 weeks past the time observed for the changes in adrenergic release, the data suggest that these postsynaptic changes are secondary to this slowly developing presynaptic adaptation in the instance of at least one antidepressant.

Noradrenergic local negative feedback control, based in part on "autoreceptors," is responsible for the modulation of the release of norepinephrine through both the amount of norepinephrine release per impulse and also the readiness of neuronal discharge (Langer, 1977). We have proposed previously that an overly stringent feedback system could impair the capacity of the catecholamine pathways to convey information adequately during depression (Cohen et al., 1980). The present data support the role of some antidepressants in potentially resetting this mechanism as an important component of 
the molecular process of antidepressant efficacy, a process which increasingly is being recognized as a complex multicomponent series of receptor and other neurochemical adaptations that take place secondary to drug-induced perturbations of the catecholamine system. These changes serve to return the organism to a physiologic and behavioral functional level of normality.

\section{References}

Bergstrom, D. A., and K. J. Kellar (1979) Effect of electroconvulsive shock on monoaminergic receptor binding sites in rat brain. Nature 278: 464-466.

Bylund, D. B., and S. H. Synder (1976) Beta adrenergic receptor binding in membrane preparations from mammalian brain Mol. Pharmacol. 12: 568-580.

Campbell, I. C., D. S. Robinson, W. Lovenberg, and D. L. Murphy (1979a) The effects of chronic regimens of clorgyline and pargyline on monoamine metabolism in the rat brain. J. Neurochem. 32: 49-55.

Campbell, I. C., D. L. Murphy, D. W. Gallager, J. F. Tallman, and E. F. Marshall (1979) Neurotransmitter-related adaptation in the central nervous system following chronic monoamine oxidase inhibition. In Monoamine Oxidase: Structure, Function, and Altered Functions, T. P. Singer, R. W. Von Korff, and D. L. Murphy, eds., pp. 517-530, Academic Press, New York.

Cohen, R. M., I, C. Campbell, M. R. Cohen, T. Torda, D. Pickar, L. J. Siever, and D. L. Murphy (1980) Presynaptic noradrenergic regulation during depression and antidepressant drug treatment. Psychiatry Res. 3: 93-105.

Cohen, R. M., I. C. Camphell, M. Dauphin, J. F. Tallman, and D. L. Murphy (1982) Changes in alpha- and beta-receptor densities in rat brain as a result of treatment with monoamine oxidase inhibiting (MAOI) antidepressants. Neuropharmacology 21: 293-298.

Crews, F. T., and C. B. Smith (1978) Presynaptic alpha-receptor subsensitivity after long-term antidepressant treatment. Science 202: 322-324.

Daly, J. W., W. Padgetl, Y. Nimitkitpaison, C. R. Creveling, D. Cantacuzene, and K. L. Kirk (1980) Fluoronorepinephrines: Specific agonists for the activation of alpha and beta adrenergic-sensitive cyclic AMP-generating systems in brain slices. J. Pharmacol. Exp. Ther. 212: 382-389.

De Langen, C. D. J., F. Hogenboom, and A. H. Mulder (1979) Presynaptic noradrenergic $\alpha$-receptors and modulation of ${ }^{3} \mathrm{H}$ noradrenaline release from rat brain synaptosomes. Eur. J. Pharmacol. 60: 79-89.

Dibner, M. D., and P. B. Molinoff (1979) Agonist induced change in beta-adrenergic receptor density and receptor modified responsiveness in slices of rat cerebral cortex. J. Pharmacol. Exp. Ther. 210: 433-439.

Frazer, A., G. Pandey, J. Mendels, S. Neeley, M. Kane, and M. E. Hess (1974) The effect of tri-iodothyronine in combination with imipramine on $\left[{ }^{3} \mathrm{H}\right]$-cyclic AMP production in slices of rat cerebral cortex. Neuropharmacology 13: 1131-1140.

Johnson, R. W., T. Reisne, S. Spotnitz, N. Wiech, R. Ursillo, and H. I. Yamamura (1980) Effects of desipramine and yohimbine on $\alpha_{2}$ and $\beta$-adrenoreceptor sensitivity. Eur. J. Pharmacol. 67: 123-127.

Kistler, K., and J. N. Davis (1980) $\beta$-Adrenergic supersensitivity in rat brainstem during clonidine withdrawal. Life Sci. 26: 1053-1059.

Kleinbaum, D. G., and L. L. Kupper (1978) Applied Regression Analysis and Other Multivariable Methods, Duxbury Press, North Scituate, MA.
Langer, S. Z. (1977) Presynaptic receptors and their role in the regulation of transmitter release. $\mathrm{Br}$. J. Pharmacol. 60: 481-497.

Lowry, O. H., N. J. Rosebrough, A. L. Farr, and R. J. Randall (1951) Protein measurement with the Folin phenol reagent. J. Biol. Chem. 19.3: 265-275.

Maggi, A., D. C. U'Prichard, and S. J. Enna (1980) $\beta$-Adrenergic regulation of $\alpha_{2}$-adrenergic receptors in the central nervous system. Science 207: 645-646.

Mishra, R., A. Janowsky, and F. Sulser (1980) Action of mianserin and zimelidine on the norepinephrine receptor coupled adenylate cyclase system. Neuropharmacology 19: 983-987.

Morris, M. J., J. -L. Elghozi, J. -P. Dausse, and P. Meyer (1981) $\alpha_{1}$ and $\alpha_{2}$ adrenoreceptors in rat cerebral cortex: Effect of frontal lobotomy. Naunyn Schmiedebergs Arch. Pharmacol. 316: 42-44.

Rosenblatt, J. E., C. P. Pert, J. F. Tallman, A. Pert, and W. E. Bunney, Jr. (1979) The effect of imipramine and lithium on alpha and beta-receptor binding in rat brain. Brain Res. 160: 186-191.

Salomon, Y., C. Londos, and M. Rodbell (1974) A highly sensitive adenylate cyclase assay. Anal. Biochem. 58: 541-548.

Scatchard, G. (1949) The attractions of proteins for small molecules and ions. Ann. N. Y. Acad. Sci. 51: 660-672.

Schultz, J. (1976) Psychoactive drug effects on a system which generates cyclic AMP in brain. Nature 261: 417-418.

Schwabe, U., M. Miyake, Y. Ohga, and J. W. Daly (1976) 4-(3-Cyclopentyloxy -4 - methoxy - phenyl) - 2-pyrrolidone (ZK62711): A potent inhibitor of adenosine cyclic $3^{\prime}, 5^{\prime}$-monophosphate phosphodiesterases in homogenates and tissue slices from rat brain. Mol. Pharmacol. 12: 900-910.

Schweitzer, J. W., R. Schwartz, and A. J. Friedhoff (1979) Intact presynaptic terminals required for beta-adrenergic receptor regulation by desipramine. J. Neurochem. 33: 377-379.

Segal, D. S., R. Kuczenski, and A. J. Mandell (1974) Theoretical implications of drug-induced adaptive regulations for a biogenic amine hypothesis of affective disorder. Biol. Psychiatry 9: 147-159.

Shimizu, M., J. W. Daly, and C. R. Creveling (1969) A radioisotopic method for measuring the formation of adenosine $3^{\prime}$. $5^{\prime}$-cyclic monophosphate in incubated slices of brain. J. Neurochem. 16: 1609-1619.

Siever, L. J., R. M. Cohen, and D. L. Murphy (1981) Antidepressants and $\alpha_{2}$-adrenergic autoreceptor desensitization. Am. J. Psychiatry 138: 681-682.

Skolnick, P., L. P. Stolvey, J. W. Daly, E. Hogler, and J. N. Davis (1978) Binding of $\alpha$-and $\beta$-adrenergic ligands to cerebral cortical membranes: Effect of 6-hydroxydopamine treatment and relationship to the responsiveness of cyclic AMPgenerating systems in two rat strains. Eur. J. Pharmacol. 47: 201-210.

Smith, C. B., J. A. Garcilla-Sevilla, P. J. Hollingsworth (1981) Alpha-2-adrenoceptors in rat brain are decreased after longterm tricyclic antidepressant drug treatment. Brain Res. 210: $413-418$.

Spyraki, C., and H. C. Fibiger (1980) Functional evidence for subsensitivity of noradrenergic $\alpha_{2}$ receptors after chronic desipramine treatment. Life Sci. 27: 1863-1867.

Stone, E. A. (1981) Mechanism of stress-induced subsensitivity to norepinephrine. Pharmacol. Biochem. Behav. 14: 719-723.

Stone, E. A., and D. C. U'Prichard (1981) $\left[{ }^{3} \mathrm{H}\right]$-Dihydroalprenolol binding in the rat brainstem. Eur. J. Pharmacol. 75: 159-161.

Su, Y. -F., T. K. Harden, and J. P. Perkins (1980) Catecholamine-specific desensitization of adenylate cyclase: Evidence for a multistep process. J. Biol. Chem. 255: 7410-7419.

Sulser, F., J. Vetulani, and P. Mobley (1978) Mode of action of antidepressant drugs. Biochem. Pharmacol. 27: 257-261. 
Svensson, T. H., and T. Usdin (1978) Feedback inhibition of brain noradrenaline neurons by tricyclic antidepressant: Alpha-receptor mediation. Science 202: 1089-1091.

Tang, S. W., D. M. Helmesfe, and H. C. Stancer (1978) The effect of acute and chronic desipramine and amitriptyline treatment on rat brain total 3-methoxy-4-hydroxyphenylglycol. Naunyn Schmiedebergs Arch. Pharmacol. 305: 207-211.

U'Prichard, D. C., D. A. Greenberg, and S. H. Snyder (1977) Binding characteristics of a radiolabeled agonist and antagonist at central nervous system alpha noradrenergic receptors. Mol. Pharmacol. 13: 454-473.

Vetulani, J., R. J. Stawař, and F. Sulser (1976a) Adaptive mechanisms of the noradrenergic cyclic AMP generating system in the limbic forebrain of the rat. Adaptation to persistent changes in the availability of norepinephrine. J. Neurochem. 27: 661-666.

Vetulani, J., R. J. Stawarz, J. V. Dingell, and F. Sulser (1976b) A possible common mechanism of action of antidepressant treatments. Naunyn Schmiedebergs Arch. Pharmacol. 293: 109-114.

Vizi, E. S. (1979) Presynaptic modulation of neurochemical transmission. Prog. Neurobiol. 12: 181-290.

Wolfe, B. B., T. K. Harden, J. R. Sporn, and P. B. Molinoff (1978) Presynaptic modulation of beta adrenergic receptors in rat cerebral cortex after treatment with antidepressants. J. Pharmacol. Exp. Ther. 207: 446-457. 